\title{
Contestation and the Roles of Islam in the Public Sphere: A Sociological Analysis of Religious Secularization in Indonesia and the West
}

\author{
DOI 10.18196/AlIJIS.2020.0119.154-174
}

\section{MOHAMMAD TAKDIR}

Institut IImu Keislaman Annuqayah Guluk-Guluk Sumenep

Email: mohammadtakdir86@gmail.com

\begin{abstract}
This study aims to explain the contestation of Islam in the public sphere. As the majority religion, Islam always presents a debate about the position of Islam in the public sphere which is often misused for political and power interests. This study uses a comparative study between secularization practices in Indonesia and the West. The theory used in this study is Jurgen Habermas' view of the public sphere, which is an open means of making every citizen a communicative society. This study shows that the contestation of Islam in the public sphere is very hard by following the ideology of a country in placing symbols and Islamic identities in the public sphere. In Indonesian context, restrictions on religious expression cannot be restricted, let alone to be prohibited by the state as the holder of power.

Keyword: Contestation of Islam, Religious Secularization, Public Sphere
\end{abstract}

\footnotetext{
ABSTRAK

Artikel ini bertujuan untuk menjelaskan kontestasi Islam dalam ruang publik. Sebagai agama mayoritas, Islam selalu menghadirkan perdebatan tentang posisi Islam di ruang publik yang sering disalahgunakan untuk kepentingan politik dan kekuasaan. Artikel ini menggunakan studi komparatif antara praktik sekularisme di Indonesia dan Barat. Teori yang dipakai dalam artikel ini adalah pandangan Jurgen Habermas tentang ruang publik, yang merupakan sarana terbuka untuk menjadikan setiap warga sebagai masyarakat komunikatif. Artikel ini menunjukkan bahwa kontestasi Islam dalam ruang publik begitu sangat keras sesuai dengan ideologi dari sebuah negara dalam menempatkan simbol dan identitas Islam pada ruang publik. Dalam konteks Indonesia, pembatasan-pembatasan ekspresi keagamaan, tidak bisa dibatasi apalagi sampai dilarang oleh negara sebagai pemegang kekuasaan. Kata Kunci: Kontestasi Islam, Sekularisme Agama, Ruang Publik
} 


\section{INTRODUCTION}

Today, the study about Islam increasingly occupies an important position in responding to the issue of nationalism that experiences ups and downs along with the swift intolerance and anarchism in Indonesian society. As a religion that is considered tolerant, Islam faces a great challenge in dealing with all the accusations addressed to adherents who often act aggressively and radically in solving the problems of this very diverse nation. The diversity of the Indonesian nation is undeniable in the midst of the development of a democratic system and the concept of pluralism which is an inevitability of history in an Indonesian frame. As a historical necessity, pluralism must be seen as a gift that brings harmony to the lives of religious people. ${ }^{1}$ Although it must be realized that many challenges and threats must be faced in caring for diversity in this motherland. The diversity of the Indonesian people must always be the glue of unity and integrity because this nation was formed based on religious nationalism.

The thought between nationalism and Islam, often giving birth to debates and acts of violence that threaten the pillars of nationalism and the philosophy of Pancasila which are the ideology of the nation. Before Indonesia's independence, the nation's founders were directly involved in the formulation of the state ideology as the main philosophy. With the spirit of unity, this nation was formed based on a nation-state as the basis of the state. Since then, the debate about the relationship between religion and the state has become a very luxurious issue in the life of the nation and state. The proof, religion in its development is not just a matter of individual beliefs, but also a part of public issues that often cause conflicts among religious communities themselves. $^{2}$

The issue of religious debate and power, in turn, creates political pragmatism which results in the loss of substantive values from the concept of religion. When the essential values contained in religion are tainted by political interests, then of course it has an impact on the sacral of the teachings of the religion itself. The proof is that when there is a moment for the regional head election, religious language is always used as an instrument to reap votes. Many of the people are trapped by the politicization of religion that is played by regional head candidates to smooth the ambition to win in the contest of democratic parties.

If the vision of religion is misused to achieve the desires of power, then religion will lose its identity as a guide for human life. Islam as a religion is 
not merely formalistic-substantivity but has plagued the political-pragmatic content. The formalistic dimension tends to prioritize form rather than content, which in turn only gives birth to religious symbolism. In the essentialist dimension, Islam should prioritize the context rather than the text, which focuses on the practice of the values of religious teachings. Islamic repositioning does provide an ideal guarantee for the inner peace of man, on the other hand, he is infected with a virus called the power syndrome. True Islam must focus on the essence of transcendental, not trapped in the impression of the eroticism of power, which carries worldly desires rather than spiritual piety. Many Islamic politicians continue to spread the debate on more universal aspects until they merge in the search for religious and political identity. Religious identity does provide personal motivation in building power relations. Likewise, with politics as the main vehicle for the ruling elite to embrace and maintain power for personal and group interests.

In the aspect of spirituality, the substance of religion must be recognized as far different in the domain of the state (power). Islam as religion guides its people to carry out good deeds that bring benefits to others. Meanwhile, the state (power) refers more to the realm of interests and satisfaction in achieving personal ambition. Not surprisingly, power is synonymous with "hegemony" (the superiority of one country over another country, which has the highest power to show the political domination). Religion and true power are related to one another. However, it still raises a very sharp polarization. It can allow the concept of religion to be tarnished by lust for power. This issue requires a meeting point or solution to compromise between religious and political interests (power). ${ }^{3}$ This fact has logical consequences on religion (Islam) being able to enter the wider public sphere and play an important role in the dynamics of plural national life. Among the several portraits of religious expansion into the region at the global level is the Islamic revolutionary movement in Iran, ${ }^{4}$ the development of a democratic climate, the rampant phenomenon of spirituality, and acts of terrorism that are considered extraordinary crimes. ${ }^{5}$

The presence of religion in the public sphere can in turn have enormous implications for the life of religious people. In the Indonesian context, the presence of Islam in a variety of global issues may present a dilemma between maintaining private space and engaging in public space. As well as being a carrier of peace and harmony, Islam can also be a source of division, dissension, and exclusivity. It depends on each adherent in practicing the 
teachings of Islam by the guidance of the Prophet Muhammad as a bearer of mercy for the entire universe. The involvement of religion (Islam) in the public sphere, can be very dangerous if there is no clear formulation about which areas are included in the privatization space and which are included in the public sphere. On the one hand, the role of religion in public life is so dominant, because it has become a way of life for a human being. That is where critical-transformative studies are important in mapping private and public areas to uphold nationalist values (nationalism) and democracy that do not conflict with the foundation of religion or the state.

As a democratic country, Indonesia must avoid inculcating nationalism and pluralism values that are tamed by the politics of harmonization for development. ${ }^{6}$ At this point, the relationship between Islam and pluralism often brings problems and conflicts among the people. It can even lead to fatal violence for national unity and integrity. The presence of Islam in the context of national plurality must be addressed wisely so that no negative sentiments emerge amid people's lives. The presence of Islam that is too entered into the public sphere, can lead to dangerous public sentiments. ${ }^{7}$

This article effort to explain the contestation and the role of Islam in the public sphere. The contestation of religion (Islam) and power (the state) focused on religious symbols and identities that were used as tools to embrace power and political interest. By placing Islam in the public sphere as a plural inevitability and reflecting openness of interaction in the reality of pluralism, the goal of creating a healthy process of democratization and integrity can become reality.

\section{THE CONCEPT AND CONTESTATION OF THE PUBLIC SPHERE: FREEDOM OF EXPRESSION ACCORDING TO JURGEN HABER- MAS}

What is the historical context of religious contestations in public spaces that can be consumed by multicultural societies? What does Jurgen Habermas think about the notion of public space from a sociological perspective? Is there an open space that can be entered into religious areas regarding the constraints that are egalitarian and humanist for the creation of freedom and independence in the public sphere?

The term public space was first introduced by the German philosopher, Jurgen Habermas, which is summarized in a book published in 1962 and also in the form of a short article published around $1964 .^{\circ}$ In both his works, 
Habermas asserted that the birth of democracy in Europe originated in public space which grew and developed among bourgeois society. For Habermas, public space is a shared space or house that enables the community to be actively involved in fighting for the public interest. ${ }^{9}$

The emergence of social institutions, print media, and social media that began to develop in Europe in the 18th century, provides an opportunity for the creation of a holistic openness to build a culture of political participation (political participation) that is integrative. The rise of capitalism in Europe must be recognized as the main embryo and locus for the growth of democracy which gives freedom to express all hidden creativity and skills. The availability of such open space marks the beginning of the development of social networking, which has emerged as the culmination point of the progression of information technology.

The development of the concept of public space in the 18th century must be recognized as a synopsis leap of scientific and technological progress that reflects the presence of social media that is developing so rapidly in guarding the interests and needs of the public so large. The dynamics of the public sphere in the 18th century for Habermas is an ideal form of community involvement in discussing some issues relating to public interests holistically.

In the public sphere, the media plays an important role in controlling state policies that are considered not transparent. Media discourse does not merely play in the realm of information and delivery of news but is increasingly widened in the consumer and commodity aspects. The existence of the media can play an important role in providing information and knowledge to the public. However, the media can also be an intellectual syndrome aided by the capitalist hands that accompany it. In other words, the media are misused for propaganda or hidden interests, not as a means to spread information and shared interests. ${ }^{10}$

Habermas analyses the key role of public space in political formations in a climate that is completely open and allows the creation of a communicative society without borders. For Habermas, public space is a space of communication to run a democratic system more openly. Habermas was very impressed with the views of Immanuel Kant, who he considered had played an important role in his academic career. Habermas cites Kant's view that public space is formed more as a rational argument than about the identity of those who put forward the argument. Nevertheless, Habermas has criticized Kant for his elitist and rather bourgeois understanding of the dynamics of public 
space. According to Habermas, Kant's ideas related to public space were based on the bourgeois ideology that placed the elite class. ${ }^{11}$

Nevertheless, Habermas remains critical of the dynamics of public space practiced in the modern democratic system. For Habermas, the theory of mass communication can open wider public spaces so that people can contribute to the development of a democratic system. While the concern of the development of this communication theory is the expansion of quantitative participation, which means a decrease in quality. The proof, some circulation in the public sphere is difficult to harmonize with the communication model that became Kant's political imagination when he discussed the public sphere as "exchange in the academic field." 12 For Habermas, mass democracies in the post-industrial capitalist era in turn can continue the principles of a constitutional liberal state in the hope of being by the mandate of public space that functions as a means of political participation. ${ }^{13}$

The model of public space defended by Kant tended to be hampered by the material conditions of society in the eighteenth century- a condition of society that was not controlled by the mass media, was not globalized and was characterized by differences in the relatively clear demarcation between the political and economic levels. In Habermas's interpretation, these conditions limit Kant's conception of the public sphere, an idea which refers to the participation of individuals in public space being limited in established opinions and moral decisions. ${ }^{14}$

For Habermas, public space concerns the nature of our attention to others and the reach of political involvement. Without attention to others, the ideals of involvement, and participation to achieve collective well-being, will only be space without meaning and orientation. The conception of a communicative society substantially modifies the notion of public space. This is because the public sphere provides open space for anyone to contribute together with the community in fighting for the public interest. ${ }^{15}$ Habermas stated that public space is a mass communication that is open to anyone to express their aspirations and views about the common interests as citizens. Habermas's idea of public space not only provides accreditation for individuals and groups to engage in social activities for the common good. That is, public space becomes a medium for every citizen to communicate without being hampered by their background, social status, culture, and religion. 


\section{DEPRIVATIZATION: LONGING FOR RELIGIOUS SECULARIZATION}

Today, public rationality is a catalyst in moving people to participate in the interests of social change. However, public rationality is often misused to position the dominant private sphere to smooth ideological-political interests. There are at least four main prerequisites that are indicators of public space inclusiveness. First, community participation in creating a conducive life climate. Second, relationships and interactions with other groups must be based on shared interests. Third, the ideas to be echoed in the public sphere must represent the interests of the public at large. Fourth, involving the government as the policyholder and controller of every rule in society. ${ }^{16}$

Then, how is the position of the public in the modernization of formal institutions? In the context of secular institutions, public space seems to be increasingly free without limits in managing the diversity of people's lives. The proof, religious institutions are more regarded as private institutions that cannot be used for the public interest. In other words, religious institutions are displaced by institutions that are very rationalistic and formalistic. ${ }^{17} \mathrm{Mod}-$ ern life does have implications for the strengthening of individualistic attitudes and the fading sense of social solidarity in community life. However, it does not necessarily undermine the existence of religion for the lives of individuals and society. In Emile Durkheim's view, religion functions as a social glue that can play a role in increasing the spirit of solidarity among the people. ${ }^{18}$ No wonder religion has an important role in the public sphere, because it can be a social motivator and binder.

At first, religion was private, but when it was practiced by the community, it had entered the public sphere. This becomes important to identify areas of religion that are truly private and that resonate in the public sphere. In the context of religious creed and ritual, religion occupies a position in the private sphere and the state does not have the authority to regulate and interfere in matters of public belief. The aspects of belief and ritualistic are subjective and private because it is related to human relations and God. ${ }^{19}$

In other areas, religion also has an interest in moral issues, attitude, social relations, and a guarantee of life for fellow human beings. This aspect is directly related to the social dimension that influences attitude patterns and ways of acting in people's lives. In other words, religion is not just private, but it has an interest in the social dimension that reflects the orientation of religion for the benefit of humanity. This is because the presence of religion is not only manifested in the form of human service to God but also service to 
fellow human beings.

In the context of religion, secularization calls for privatization, which reflects the private and public spheres separate from one another. Private space is an individual territory that no one can intervene in, because everyone has the right to choose and determine his future, including in matters of belief in religion. In a secular context, Islam seems to occupy its locus in the private sphere. Meanwhile, public space can be understood that every citizen has the freedom to express his views by the will and common interests.

As a democratic country, the Indonesian government has no right to enter the private dimension, especially about matters of religious belief. The position of the state must be objective and not too enter into the area of belief of its citizens. If a country deals with permits in the construction of places of worship, the state has exceeded its authority as a policyholder in regulating its citizens. Although it must be admitted that there are limitations in practicing freedom of belief, it is only limited to the problem of freedom that goes beyond the boundaries of fairness, causes criminal acts, unrest in society. ${ }^{20}$

\section{THE OBJECTIVITY OF RELIGION IN THE PUBLIC SPHERE: A SO- CIOLOGICAL ANALYSIS OF RELIGIOUS SECULARISM IN INDO- NESIA AND THE WEST}

What exactly is the concern of religion when it directly touches the public space? This question becomes important to answer doubts about the position of religion that seems to be misused for the sake of power and identity politics which increasingly colors the nation's contestation on a global scale. The involvement of religion in the public sphere will certainly lead to sectarianism or the practice of identity politics that is deeply rooted in the joints of Indonesian people's lives. Likewise, the seeds of authoritarianism can emerge at any time depending on the political situation behind them. In the threat of sectarianism, religion must at least be able to appear as a pioneer of transformation to overcome problems in the public sphere.

The existence of religion must be objectified to be involved in life dimensions related to public matters. The objectification of religion allows religion not to appear sectarian, discrimination, and exploitative towards social changes that occur in people's lives. Placing religion in the public sphere does not mean that it wants to injure the sacredness that is contained, but rather seeks to bring religion to the efforts to overcome problems related to the welfare of life and economic inequality that colors the hustle and bustle of the life of 
this nation.

Then, what about the influence of religion in the life of the state and politics ridden by the interests of power? To objectify the role of religion in the public sphere, the position of the state as the holder of control of power must be neutral, not necessarily nullify the existence of religion. As a pluralistic nation, the state must protect and act fairly for all religions. ${ }^{21}$ This is because this nation was founded not for the sake of just one religion, but to accommodate all the flow of beliefs and religions.

If there are efforts to make Indonesia a religious state, it means that it betrayed the legacy of the founders of this nation who had fought for the unity of people from various regions. In countries that adopt secular forms as the basis of the state, it seems that this may be a quite relevant choice. For example, Turkey is a secular state that separates from the role of religion. The Islamic government system that once reached the culmination of progress, has now been removed and has chosen to become a secular state. During its development, Turkey adopted a law banning the families of government officials from wearing headscarves in public spaces. The practice of secularism in Turkey is indeed very strict and limits the expression of religious diversity in society. This is different from the United States which does not interfere too much in matters of the beliefs and expressions of the religious diversity of its private citizens. ${ }^{22}$

The model and practice of secularism in Turkey according to Azyumardi Azra as secularism that is not friendly to religion. Since Kemal Attaturk's government, the practice of secularism in Turkey has been implemented. Secularism in Turkey is very extreme and in no way reflects harmony with religion. One way is to change adzan from Arabic to Turkish. Such rules become a syndrome in the life of religious people in Turkey because the call to prayer does not belong to the territory of the country. Extremely secularist practices also occur in France. In a law implemented in France, Muslim women are prohibited from wearing headscarves in public places. The wearing of headscarves in public spaces is seen as a reflection of sectarianism, which can divide national solidarity and unity. All forms of religious expressions and actions in the public sphere must not be carried out for any reason, because they are considered as polluting the secular environment. This is because, in many secular countries, where secularism initially emerged as a vehicle for protecting against of religious domination, there has subsequently been a shift toward a more widespread diversity of religious belief. ${ }^{23}$ 
In the Indonesian context, restrictions on religious expression are not possible in the public sphere. During the month of Ramadan, various religious expressions continue to be carried out according to the schedule, such as the activities of the Qur'an and religious lectures using loudspeakers. This condition makes Indonesia a Muslim-majority country, having an open space to discuss the issue of secularization that is deeply rooted in the community. Between religion and the state has a balanced role in regulating its citizens in carrying out all forms of religious expression. ${ }^{24}$

Referring to the condition of the pluralistic Indonesian society, the practice of secularism that might be applied is by referring to the American model of secularism that provides guarantees and protections for its citizens to practice religious practices freely. Although considered a secular state, America does not intervene in matters of belief or worship that are the right of every human being to choose their respective paths of religion. America gives freedom to every citizen to express religion without anyone prohibiting it. In other words, America is very democratic in matters of religious and political relations. ${ }^{25}$

The model of secularism adopted in America is considered as secularism that is friendly to religion. Although it must be recognized that America has divided political (state) and religious areas. However, it does not eliminate the role of religion in public life. So, as long as it is still related to private matters, there is no prohibition for anyone, including wearing headscarves in public places. As a democratic country, America is an example of a secular state model that is friendly to the opening of freedom and hope for humanity. Although considered as a secular state, but America can be a role model of a country that gives freedom for each individual to carry out rituals and religious expressions by their beliefs. America's status as a secular state has become an advantage for minorities in expressing their religious identity.

Among some secular countries, America is a portrait of a country that can be neutral and objective in seeing the role of religion in social life that is not separate sectarian or communal issues. In the life of a pluralistic and democratic society, the existence of religion is a matter of life for all policies concerning the public interest. Especially regarding obedience to the rules, norms, and religious values that guide the lives of American citizens. In American political life, religious doctrine is relevant to contemporary public issues that try to investigate the influence of religion on political attitude, which increasingly shows the involvement of religion in the public sphere. ${ }^{26}$ 
The objectified religious model in the public sphere can open the way to solving real problems that occur in society. Moreover, Indonesia is not a secular state and a homogeneous religious state in solving every national problem. Indonesia is a Pancasila country that accommodates all groups and religions in one motto, namely unity in diversity. The advantage of the nation does not adhere to a secular or religious state, as seen in the dynamics of people's lives lately. The founders of this nation, of course, have consideration and maturity in building a big ideology that can later influence the nation's future. Soekarno was well aware that Indonesia could not be a secular state because the majority of Indonesia were religious people. Indonesia is also not a homogeneous country, which only adheres to one ideology and religion, but it is a pluralistic nation with all the wealth of identity, tradition, culture, customs, ethnicity, and religion. So, all society must respect the rights of minority groups based on the spirit of kinship and brotherhood. ${ }^{27}$

Although Indonesia takes the ideology of Pancasila as the basis of the state, it does not denigrate religious teachings as a way of life for pluralistic societies. Instead, the philosophical values that are manifested in the ideology of Pancasila, reflect religious teachings that are not in conflict, both ideologically, theologically, and sociologically. Although Indonesia is inhabited by various religions and religious ideologies that are very rich, it does not necessarily make Indonesia a religious state. According to Azyumardi Azra, very difficult to imagine that Indonesia could be transformed into an Islamic state. ${ }^{28}$ This is because Indonesia appreciates the diversity of religions and ideologies that can support each other in maintaining integrity and national unity.

Then, every citizen must have an open attitude towards other groups or religions because we are united by the blood of Indonesia. Every element of the nation in this country must make Pancasila a practice and practice that gives freedom of expression based on its beliefs. Religion is not a reason to curse each other and close themselves with other groups or religions, because this nation is united not based on religion, but by the spirit to respect the diversity that exists. The presence of religion can be an adhesive between all elements of the nation, as well as a source of divisions because of differences in identity and different religious ideologies. At least, this nation has learned from a variety of possibilities that can threaten the integrity of the nation so that it can manage the diversity of identities in the public sphere. ${ }^{29}$ 


\section{CONTESTATION ON ISSUES AND ROLE OF ISLAM IN THE PUB- LIC SPHERE: AN EFFORT TO ACHIEVE OF PEACE ISLAM}

The presence of Islam in the dynamics of public space over the past two decades, not only because Islam is often associated with various events of violence, radicalism, and acts of terrorism, but also caused by waves of globalization that brought radical changes in people's lives. The presence of Islam in the public sphere seems to increase the dynamics of national politics. Beyond the ideology and developing political facts, the dynamics of Islam in public spaces is also marked by the expression of cultural symbols, such as religious films, Islamic textbooks, Islamic defense actions, propaganda and virtual recitation through social media, and the expression of other symbols that participate opening new horizons in the dynamics of Islam in the public sphere. ${ }^{30}$

The presence of Islam in the public sphere, very important in making people aware of being mature in addressing any sensitive issues related to Islam that are becoming public consumption. In contrast to the concept of secularization which assumes that religion only occupies a position in the private sphere, while democracy requires a limitation between the private sphere and the public. Even private issues such as marriage, divorce, maintenance, and relations between parents and children, can become a very important discourse in the political arena when these issues affect gender equality and human rights. A forum for democracy is often fought by religious groups to strengthen the existence and legitimacy of the public sphere. ${ }^{31}$

In the context of Indonesia, the contestation of issues and Islamic studies in the public sphere is sufficient to get attention and experience a lot of developments by the climate of democracy which has an extraordinary influence on the future of Indonesia. The study of Islam in the public sphere is important to provide an integrative understanding to the public that in a country as diverse as Indonesia, the reality of religious diversity can potentially lead to problems that require the right formulation of basic philosophies that can accommodate all the aspirations of the community multi-religious. Religious diversity is not only influenced by issues present in the public sphere, but also by contestation and negotiation between religious groups with ideological differences and political orientation. With another word, public sphere is not only a contestation between Islam and secularism, but also among the proponent of social movements in Indonesia. ${ }^{32}$

Since the second half of 1990, the study of Islam as a phenomenon in the 
public sphere has emerged coloring the hustle and bustle of this nation's journey. The development of Islamic studies in the public sphere is certainly supported by several figures who are concerned about promoting Islamic issues as a religion for human beings. The attention of the figures in researching Islam in Indonesia is not only due to its uniqueness as a Pancasila state but is also influenced by the development of democracy which provides a massive change in the dynamics of politics.

Among these figures are Robert W. Hefner, Kenneth M. George, and John R. Bowen, who aggressively made a breakthrough in making Islam in Indonesia a major study that was quite attractive. Hefner, for example, tried to analyse the ideological struggle between supporters of the Media Propagation magazine which was controlled by the Indonesian Islamic Propagation Council (DDII) and the Republika newspaper which was supported by activists from the Indonesian Muslim Intellectuals Association (ICMI). ${ }^{33}$

Besides, there is also a figure who is very influential in the study of Islamic issues in Indonesia, namely Kennet M. George. ${ }^{34}$ In a study of Islam in Indonesia, George analysed the Istiqlal Festival 1994-1995, which was fully supported by the New Order government. In this festival, various performing arts were held and Muslim scholars were invited to speak in a dialogue about the Islamic culture of the archipelago. What attracted the public's attention from this festival was a large manuscript called the Istiqlal Manuscripts. George considered that the Istiqlal Manuscripts were a good example of how Islam was presented in the public sphere at the end of the New Order. ${ }^{35}$

In addition to the two figures mentioned above, there is also a researcher who tries to analyse the development of Islamic law in Indonesia as a public reasoning process, namely John R. Bowen. According to him, there are two types of reasoning tendencies in Islamic law in Indonesia, namely transcendental (this reasoning is related to God's will) and comprehensive (reasoning for the benefit of the people). ${ }^{36}$ These two tendencies become choices in determining the law relating to the benefit of the people.

Of the several figures who study Islam in the public sphere, at least it can be a picture of how the true face of Islam when promoted through various media. Lately, the role of Islam in the public sphere is very dominant to promote a set of Islamic nuanced labels. For example, the study of the yellow book is carried out online or virtual by some Kyai in Islamic boarding school. By using social media, such as Facebook, Instagram, and YouTube, Kyai holds live recitations through social media channels that can be reached by stu- 
dents and Muslims as a whole. The followers of virtual recitation that developed lately, not only come from the boarding school, but also from interfaith who are interested in Islamic studies that provide peace and coolness for the life of religious people.

The phenomenon of virtual recitation is increasingly lively on social media, giving a new alternative to the propaganda of Islam in the digital world. Virtual recitation is not just an interesting content of the study but also relates to the media used to spread and the promotion of Islam to the public sphere. Islamic promotion through virtual recitation can influence the public to be involved in the dynamics of the spread of Islam which is cool and peaceful. Not surprisingly, the discourse of Islamic studies in the public sphere is very intense through social media to attract interest for the public to study Islam more deeply.

The role of Islam in promoting religious issues that development is done in many ways that can support Islamic involvement when entering the public sphere. In recent years, print media have emerged that specifically promote Islamic, both related to the treasures of civilization and the struggle for the spread of Islam in various parts of the world. The emergence of the Republika, Harian Umum Pelita, Suara Muhammadiyah, Sabili, Hidayatullah, Annida, is part of the promotion of Islam in the public sphere. Not to mention the emergence of online media which is very active in voicing Islamic with various segments and offerings that interest the public.

Besides, the phenomenon of publishing Islamic books is increasingly being carried out, both academic and popular Islamic studies, including storybooks with Islamic nuances. In several well-known publishers in Indonesia, a line of publishing has appeared that specifically publishes popular Islamic books with various scientific disciplines. The publication of popular Islamic books is an attraction for readers in exploring the knowledge of Islamic studies with a simple, easy-to-understand, and enlightening presentation for the people.

The ways of promoting Islam are not only done through publishing books based on popular Islam, but also through literary works that breathe Islam through the presence of religious-style novels. One of the author's communities who actively voiced the promotion of Islam through literary works was the Forum Lingkar Pena (FLP), which was the pioneer in publishing religious novels in Indonesia. Published novels take segments of Islamic boarding schools and Islamic themes that are of interest to the young generation. ${ }^{37}$ 
The promotion of Islam in the public sphere is increasingly felt along with the development of social media, such as Facebook, Instagram, Twitter, and YouTube which are widely used as propaganda media in spreading Islam with more contemporary models and approaches. Media literate people can easily access and absorb Islamic offerings that provide enlightenment for the problems of the people. The people's acceptance of the promotion and propagation of Islam through the development of social media greatly influences their perspective in responding to the intense Islamic issues in the public sphere. For people who want to deepen their knowledge of Islam, it is easy to choose to study content that is scattered on social media with very varied themes. In the Muslim community, social media has helped significantly to promote Islam because it has the ability to develop their knowledge. ${ }^{38}$

In the studying of Islamic discourse in the public sphere, it is also important to note where these discourses come from. The selection of themes about Islamic studies that are scattered on social media is very important to anticipate the entry of radical teachings that are easily accessed by anyone. If we choose the wrong content and religious leaders in the delivery of Islamic values without knowing the ideological background and movements, then it can be very dangerous for the presence of Islam in the public sphere. This not only has an impact on the image of Islam as a cool and peaceful religion but it can also affect the way people look at the promotion strategy and Islamic values. And social media has an impact on Muslim societies because assumed as a strategy in the spreading of Islam in the public sphere..$^{39}$

Islamic movements such as Muhammadiyah and Nahdlatul Ulama, which were born from the religious traditions of these two organizations, usually offer different Islamic discourses from Islamic groups such as HTI, FPI, and MMI. The NU and Muhammadiyah organizations are two Islamic organizations that have had a great influence on people's lives. NU and Muhammadiyah not only played an important role in the founding of this nation but were also very consistent in spreading moderate Islam as a buffer for the upholding of the pillars of democracy and Pancasila which became the basic philosophy of the state. According to Robert W. Hefner, Muhammadiyah and Nadhlatul Ulama are frequently characterized as moderate Islamic organizations in terms of their religious expression. ${ }^{40}$

In the context of the spread and promotion of Islam in the public sphere, the role of the media plays an important role in influencing people's attitudes. Especially if it is supported by religious organizations that move simul- 
taneously in voicing Islamic values. If the community chooses moderate ideology and religious movements, then their perspective on Islamic issues will not be radical and tend to display a wise attitude as directed by the Prophet Muhammad. This is different from a group of people who are easily trapped by radical and extreme ideologies through hard-line Islamic organizations that are very vociferous in religious ideologies that tend to oppose the Pancasila ideology. So, their attitudes must not be much different from the ideology and religious beliefs they believe in.

By presenting the cool face of Islam through various media, Islam can be accepted as a religion that brings enlightenment and peace to all humanity. The study of Islam and pluralism in the public sphere is expected to be able to provide an understanding to the public about the importance of respecting which belongs to the private or public domain. In essence, when looking at the debate over religious issues in the context of public or private space, we must be able to take a middle way (moderate) to avoid conflict and greater disputes.

Religion is indeed a personal expression derived from subjective beliefs. However, religion is a way of life that is a source of happiness and peace for the people. When religion is practiced by people with different social backgrounds, religion must play a role in strengthening social solidarity in the public sphere so that it can have a positive impact on a shared life. Although consensus on public issues often faces many challenges, it can at least provide open space and joint dialogue to reorganize democracy and a family spirit.

Thus, lest the issue of sharia regulations be used as an obstacle to building democracy based on the principle of Pancasila which is the philosophy of this country. Although there is heated debate about this sensitive issue, it has not been in vain. This is because, Islam is a religion that is by the ideology of Pancasila as a philosophy of life that respects all diversity without seeing differences in social, political, cultural, and religious backgrounds.

\section{CONCLUSION}

This article shows that Islam faces some challenges in the public sphere, such as negative and positive challenges. Islamic challenges in the public sphere are relevant to the background of radical movements that effort to reduce Indonesian reputation as a moderate state. Some religious organizations will to Indonesia became a secular religion, such as Turkey, Prance, and 
America. Indonesia is a democratic state and based on Pancasila as state philosophy. So, all society has given liberties to the expression of identity, symbols, and religious rituals in the public sphere.

In the end, the presence of Islam in the public sphere is a good advantage for all people to support the spirit of tolerance and values of civilization in the Indonesian human spirit. If you want the public expression of religion to manifest, then every element of the nation must always accept the presence of religious expression from other religious groups. The internalization of tolerance can be realized in a more inclusive and permissive in the public sphere. Moreover, the goal of the state in principle is to prosper civil rights which must be considered together.

\section{ENDNOTES}

1 Mujiburrahman, Mengindonesiakan Islam: Representasi dan Ideologi (Yogyakarta: Pustaka Pelajar, 2008), p. 44.

2 M. Dawam Raharjo, "Agama di Ranah Publik," in Ihsan Ali Fauzi, Syafiq Hasyim, dan J.H Larmady (ed.), Demi Toleransi, Demi Pluralisme, (Jakarta: Paramadina, 2007), p. 454.

3 Mohammad Takdir, "Politisasi Agama dan Sindrom Kekuasaan," in Abdul Wahid BS (ed.), Agama dan Kekuasaan, (Yogyakarta: Obsesi Press bekerja sama dengan Grafindo, 2009), p. 87.

4 Although the pan-Islamist rhetoric was loudly touted, it was never questioned by the Iranian revolutionary movement. The Iranian Constitution does state that their spiritual leader is not necessarily an Iranian, but the citizenship law remains very strict. By using the constitutional model-changing the theocracy system into a presidential (constitutional theocracy), Iran has proven that it has succeeded in finding political space and placing the constitution as decisive for the application of the Shari'a. See Olivier Roy, Gagalnya Islam Politik, (trans.) Harimurti \& Qamaruddin (Bandung: Serambi, 2005), p. 218-219.

5 Terrorism emerged in the last century18, the terms war and violence first colored the long history of religions that sought to establish dominance and hegemony to show their respective strengths. Not surprisingly, the history of terrorism was first popularized during the French Revolution, at which time, terrorism had a positive connotation. See Noam Chomsky, Menguak Terorisme Internasional (Bandung: Mizan, 1991), p. 72

6 Mohammad Takdir, Nasionalisme dalam Bingkai Pluralitas Bangsa: Paradigma Pembangunan dan Kemandirian Bangsa (Yogyakarta: Ar-Ruzz Media, 2012), p. 23.

7 Miriam Hoexter, Shamuel N. Eisenstadt, and Nehemia Levtzion (ed.) The Public Sphere in Muslim Societies, (Albany: State University of New York Press, 2002), p. 9. 
Jurgen Habermas, "The Public Sphere: An Enclopedia Article (1964)”, Trans. Sara Lennox dan Frak Lennox, in Autum, 1974, 49-55.

9 In defining public space, Habermas does not explicitly explain the exact formulation of a shared house that can be used as the main centre in discussing something related to the interests of society at large. Nevertheless, Habermas still makes public space as part of a joint dialogue that encourages openness and freedom of thought among marginalized people and hegemony by authoritarian power. While Charles Taylor, assessing that public space is a mirror of the progress of science and technology with the development of print and electronic media that allows everyone to meet in the raising of solidarity and public interest. See Charles Taylor, "Modernity and the Rise of the Public Sphere," in The Tanner Lecture on Human Values, No. 14 (1993), pp. 220.

10 Ziauddin Sardar, Membongkar Kuasa Media (trans.), Dina Septi Utami (Yogyakarta: Resist Book, 2008), p. 18.

11 This elitist quality parallels Kant's concept of public space, which is consistently stated that he relies on an academic background as an ideal model of all exchanges and battles in the dynamics of politics including the public sphere.

12 Giovanna Borradori, Filsafat dalam Masa Teror: Dialog dengan Jurgen Habermas dan Jacques Derrida (trans.), Alfons Taryadi (Jakarta: Penerbit Buku Kompas, 2005), p. 83.

13 Jurgen Habermas, "Further Reflection on the Public Sphere," Craig C. Valhoun (ed.) Habermas and the Public Sphere (Cambridge: MIT Press, 1992), 441.

14 Jurgen Habermas, Communication and the Evolution of Society (trans.), Thomas McCarthy (London: Beacon Press, 1979), p. 93; Immanuel Kant, "Perpetual Peace,” in Hans Reiss (ed.), Kant's Political Writings, (Cambridge: Cambridge University Press, 1970), p. 102.

15 Jurgen Habermas, The Structural Transformation of Public Sphere: An Inquiry into a Category of Bourgeois Society (trans.), Thomas Berger \& Frederick Lawrance (Cambridge: Polity Press, 1989), p. 233.

16 Masdar Hilmy, Islam Profetik: Substansiasi Nilai-Nilai Agama dalam Ruang Publik (Yogyakarta: IMPULSE, 2008), p. 123.

17 Hilman Latief, "Agama dan Ruang Publik: Antara Profanisasi dan Sakralisasi," Kompas, 27 Februari 2005.

18 Emile Durkheim, The Elementary Forms of Religious Life, (trans.) J. Swain (New York: SUNY Press, 1961), p. 475.

19 M. Dawam Rahardjo, "Agama di Ranah Publik", p. 453; Mohammad Takdir, "Membumikan Spirit Kebebasan Beragama dan Berkeyakinan", in Saidiman Ahmad, Husni Mubarak, dan Testriono (ed.), Pembaruan Tanpa Apologia: EsaiEsai tentang Ahmad Wahib, (Jakarta: Yayasan Wakaf Paramadina, 2010), p. 102.

20 Jose Casanova, Public Religion in the Modern World (Chicago: University of Chicago of Press, 1994), p. 56.

21 Ibid., 455.

22 Dawam Rahardjo, in Book Introduction Budhy Munawar Rachman, Reorientasi Pembaharuan Islam, Sekularisme, Liberalisme, dan Pluralisme: Paradigma Baru Is- 
lam Indonesia (Jakarta: Paramadina, 2010), p. XXX1.

23 Judith Butler (et.al), The Power of Religion in The Public Sphere (New York: Columbia University Press, 2011), p. 6.

24 Ibid., XXXII.

25 David C. Leege dan Lyman A. Kellstedt, Agama dalam Politik Amerika, (trans.) Debbie A. Lubis dan A. Zaim Rofiqi (Jakarta: Kedutaan Besar Amerika Serikat Bekerjasama dengan Freedom Institute dan Yayasan Obor Indonesia, 2006), p. 195-196.

26 Christopher Gilbert, Religious Environment and Political Actors (Washington DC: Washington University, St. Louis, 1991), p. 123.

27 Yudi Latif, Wawasan Pancasila, (Bandung: Mizan, 2018), p. 165.

28 Azyumardi Azra, Indonesia, Islam, Democracy: Dynamics in a Global Context (London: Equinox Publishing, 2006), p. 6.

29 Budhy Munawar Rachman, Reorientasi Pembaharuan Islam, Sekularisme, Pluralisme, dan Liberalisme: Paradigma Baru Islam Indonesia (Jakarta: LSAP bekerjasama dengan Paramadina, 2010), p. 73.

30 Winfried Weck, Noorhaidi Hasan, dan Irfan Abubakar, Islam in the Public Sphere: The Politics of Identity and the Future of Democracy in Indonesia (Jakarta: Center for the Study of Religion and Culture (CSRC) Universitas Islam Negeri (UIN) Syarif Hidayatullah Jakarta, 2011), p. XIII.

31 Ibid., XIV.

32 Muhammad Ansor, "Post-Islamism and the Remaking of Islamic Public Sphere in Post-Reform Indonesia," in Studi Islamika, Vol. 23, No. 3 (2016), pp. 471.

33 Robert W. Hefner, "Print Islam: Mass Media and Ideological Rivalries Among Indonesian Muslim”, Indonesia, No. 64 (1997), pp. 77.

34 Kennet M. George, "Design on Indonesia's Muslim Communities," in Journal of Asian Studies, Vol. 57. No. 3 (August, 1998), pp. 693.

35 R. William Liddle, "The Islamic Turn in Indonesia: A Political explanation”, in Journal of Asian Studies, Vol. 55. No. 3 (1996), pp. 613.

36 John R. Bowen, Shari'a and Social Norms in France and Indonesia (Leiden: ISIM, 2001), p. 11; Bowen, Islam, Law, and Equality in Indonesia: An Anthropology of Public Reasoning (Cambridge: Cambridge University of Press, 2003).

37 Mujiburrahman, Mengindonesiakan Islam, p. 59.

38 M.M. Sule, "Social Media and Its Effects on Muslim Students: The Case of Nasarawa State University, Keffi, Nigeria,” in UMRAN-International Journal of Islamic and Civilizational Studies, Vol. 5, No. 2, 2018, pp. 232.

$39 \mathrm{Md}$. Tarequl Islam, "The Impact of Social Media on Muslim Society: From Islamic Perspective," In International Journal of Social and Humanities Sciences (IJSHS), Vol. 3, No. 3 (2018), pp. 95-114.

40 Robert W. Hefner, "Social Legacies and Possible Futures," In Indonesia: The Great Transition, (ed.), John Bresnan, (Lanham: Rowmah \& Littlefield Publishers, 2005), p. 75. 


\section{REFERENCES}

Ansor, Muhammad. 2016. "Post-Islamism and the Remaking of Islamic Public Sphere in Post-Reform Indonesia." Studi Islamika. 23 (3), pp. 471.

Azra, Azyumardi. 2006. Indonesia, Islam, Democracy: Dynamics in a Global Context. London: Equinox Publishing, 2006.

Borradori, Giovanna. 2005. Filsafat dalam Masa Teror: Dialog dengan Jurgen Habermas dan Jacques Derrida, trans. Alfons Taryadi. Jakarta: Penerbit Buku Kompas.

Bowen, John R. 2001. Shari'a, and Social Norms in France and Indonesia. Leiden: ISIM.

2003. Law, and Equality in Indonesia: An Anthropology of Public Reasoning. Cambridge: Cambridge University of Press.

Butler, Judith (et.al). 2011. The Power of Religion in The Public Sphere. New York: Columbia University Press.

Casanova, Jose. 1994. Public Religion in the Modern World. Chicago: The University of Chicago of Press.

Chomsky, Noam. 1991. Menguak Terorisme Internasional. Bandung: Mizan.

Durkheim, Emile. 1961. The Elementary Forms of Religious Life, trans. J. Swain. New York: SUNY Press.

George, Kennet M. 1998. "Design on Indonesia's Muslim Communities.” Journal of Asian Studies. 57 (3), pp. 693.

Gilbert, Christopher. 1991. Religious Environment and Political Actors. Washington DC: Washington University, St. Louis.

Habermas, Jurgen. 1992. "Further Reflection on the Public Sphere," in Craig C. Valhoun (ed.). Habermas and the Public Sphere. Cambridge: MIT Press.

Habermas, Jurgen, Sara Lennox dan Frank Lennox. 1997. "The Public Sphere: An Encyclopedia Article (1964). Autumn (3), pp. 49-55.

1979. Communication and the Evolution of Society (trans.) Thomas McCarthy. London: Beacon Press.

1989. The Structural Transformation of Public Sphere: An Inquiry into a Category of Bourgeois Society (trans). Thomas Berger \& Frederick Lawrance. Cambridge: Polity Press.

Hefner, Robert W. 1997. "Print Islam: Mass Media and Ideological Rivalries Among Indonesian Muslims,” Indonesia. (64), pp. 77-103.

Hefner, Robert W. 2005. "Social Legacies and Possible Futures." In Indonesia: The Great Transition, (ed.) John Bresnan. Lanham: Rowmah \& Littlefield Publishers.

Hilmy, Masdar. 2008. Islam Profetik: Substansiasi Nilai-Nilai Agama dalam Ruang Publik. Yogyakarta: IMPULSE.

Hoexter, Miriam, Samuel N. Eisenstadt, and Nehemia Levtzion (ed.). 2002. The Public Sphere in Muslim Societies. Albany: State University of New York Press.

Islam, Md. Tarequl 2018. "The Impact of Social Media on Muslim Society: From Islamic Perspective." In International Journal of Social and Humanities Sciences (IJSHS). 3, (3), pp. 95-114.

Kant, Immanuel. 1970. "Perpetual Peace," in Hans Reiss (ed.). Kant's Political Writings. Cambridge: Cambridge University Press. 
Latief, Hilman. 2005. "Agama dan Ruang Publik: Antara Profanisasi dan Sakralisasi," Kompas, 27 Februari.

Latif, Yudi. 2018. Wawasan Pancasila. Bandung: Mizan.

Leege, David C. dan Lyman A. Kellstedt. 2006. Agama dalam Politik Amerika (trans.) Debbie A. Lubis dan A. Zaim Rofiqi. Jakarta: Kedutaan Besar Amerika Serikat bekerjasama dengan Freedom Institute dan Yayasan Obor Indonesia.

Liddle, R. William. 1996. "The Islamic Turn in Indonesia: A Political explanation.” Journal of Asian Studies. 55 (3), pp. 112-138.

Mujiburrahman. 2008. Mengindonesiakan Islam: Representasi dan Ideologi. Yogyakarta: Pustaka Pelajar.

Rachman, Budhy Munawar. 2010. Reorientasi Pembaharuan Islam, Sekularisme, Pluralisme, dan Liberalisme: Paradigma Baru Islam Indonesia. Jakarta: LSAP bekerjasama dengan Paramadina.

Rahardjo, Dawam. dalam buku Kata Pengantar Budhy Munawar Rachman. 2010. Reorintasi Pembaharuan Islam, Sekularisme, Liberalisme, dan Pluralisme: Paradigma Baru Islam Indonesia. Jakarta: Paramadina.

2007. "Agama di Ranah Publik." Dalam Ihsan Ali Fauzi, Syafiq Hasyim, dan J.H Larmady (ed.). Demi Toleransi, Demi Pluralisme. Jakarta: Paramadina.

Roy, Olivier. 2005. Gagalnya Islam Politik, terj. Harimurti \& Qamaruddin. Bandung: Serambi.

Sardar, Ziauddin. 2008. Membongkar Kuasa Media, trans. Dina Septi Utami. Yogyakarta: Resist Book.

Sule, M.M. 2018, "Social Media and Its Effects on Muslim Students: The Case of Nasarawa State University, Keffi, Nigeria." UMRAN-International Journal of Islamic and Civilizational Studies. 5 (2), pp. 232.

Takdir, Mohammad. 2010. "Membumikan Spirit Kebebasan Beragama dan Berkeyakinan.” Dalam Saidiman Ahmad, Husni Mubarak, dan Testriono (ed.). Pembaruan Tanpa Apologia: Esai-Esai tentang Ahmad Wahib. Jakarta: Yayasan Wakaf Paramadina.

. 2009. "Politisasi Agama dan Sindrom Kekuasaan.” Dalam Abdul Wahid BS dkk (ed.). Agama dan Kekuasaan. Yogyakarta: Obsesi Press bekerjasama dengan Grafindo.

2012. Nasionalisme Dalam Bingkai Pluralitas Bangsa:

Paradigma Pembangunan dan Kemandirian Bangsa. Yogyakarta: Ar-Ruzz Media.

Taylor, Charles. 1993. "Modernity and the Rise of the Public Sphere." The Tanner Lecture on Human Values (14), pp. 206.

Weck, Winfried, Noorhaidi Hasan, dan Irfan Abubakar. 2011. Islam in the Public Sphere: The Politics of Identity and the Future of Democracy in Indonesia. Jakarta: Center for the Study of Religion and Culture (CSRC) Universitas Islam Negeri (UIN) Syarif Hidayatullah Jakarta. 